$\left.\begin{array}{c}\text { BIODIK: Jurnal IImiah Pendidikan Biologi } \\ \text { ISSN 2580-0922 (online), ISSN 2460-2612 (print) } \\ \text { Volume 06, Nomor 04, Tahun 2020, Hal. 442-453 } \\ \text { Available online at: } \\ \text { hIttps://online-journal.unja.ac.id/biodik }\end{array}\right)$ BIODIK

Research Article OPEN ACCESS

\title{
Analisis Relevansi Materi Superkelas Pisces dalam Aspek Penerapan IImu Taksonomi Hewan di Sekolah
}

\section{(Analysis of the Relevance of Pisces Superclass Material in the Aspect of Application Animal Taxonomy in Schools)}

\author{
Rhavy Ferdyan*, Abdul Razak, Ramadhan Sumarmin, Zulyusri \\ Universitas Negeri Padang \\ Jl. Prof. Dr. Hamka, Air Tawar, Padang, Sumatera Barat-Indonesia \\ *Corresponding Author: rhavyferdyan@unp.ac.id
}

\begin{tabular}{|c|c|}
\hline Informasi Artikel & ABSTRACT \\
\hline $\begin{array}{l}\text { Submit: } 11-10-2020 \\
\text { Diterima: } 25-11-2020 \\
\text { Dipublikasikan: } 17-12-2020\end{array}$ & $\begin{array}{l}\text { The science of taxonomy animal is a science that is constantly experiencing growth. } \\
\text { One of the objects of study of the taxonomy of animals is a superclass Pisces that its } \\
\text { application is also done at the school through the teaching of biology. To expand the } \\
\text { repertoire of science knowledge regarding Pisces, not be separated from research that } \\
\text { are continuously being developed by experts to produce discoveries about the Pisces } \\
\text { superclass which also have an impact on the discovery of new concepts. Will but the } \\
\text { content material superclass Pisces on learning and several book packages that use has } \\
\text { not been demonstrated progress hot, even still finding misconception. This is certainly } \\
\text { not appropriate if it is still implemented. Through the articles of this author will give a } \\
\text { review of the science regarding the reason for the importance of increasing the } \\
\text { relevance of the content material to expose the data and facts state of content material } \\
\text { superclass Pisces during this. Articles of this come through research by using approach } \\
\text { qualitative type of study library (library research). }\end{array}$ \\
\hline & Material, Relevance, School, Pisces Superclass, Animal Taxnomy \\
\hline Penerbit & ABSTRAK \\
\hline $\begin{array}{l}\text { Program Studi Pendidikan } \\
\text { Biologi FKIP Universitas Jambi, } \\
\text { Jambi- Indonesia }\end{array}$ & $\begin{array}{l}\text { IImu taksonomi hewan merupakan ilmu yang senantiasa mengalami perkembangan. } \\
\text { Salah satu objek kajian taksonomi hewan adalah superkelas pisces yang penerapannya } \\
\text { juga dilakukan di sekolah melalui pembelajaran biologi. Untuk memperluas khasanah } \\
\text { ilmu pengetahuan mengenai pisces, tidak akan lepas dari penelitian-penelitian yang } \\
\text { terus dikembangkan oleh para ahli untuk menghasilkan penemuan-penemuan baru } \\
\text { tentang superkelas pisces yang juga berdampak kepada penemuan konsep-konsep } \\
\text { baru. Akan tetapi konten materi superkelas pisces pada pembelajaran dan beberapa } \\
\text { buku paket yang digunakan belum menunjukkan perkembangan terkini, bahkan masih } \\
\text { ditemukannya miskonsepsi. Hal ini tentu tidak tepat jika masih diterapkan. Melalui artikel } \\
\text { ini penulis akan memberikan kajian ilmiah mengenai alasan pentingnya meningkatkan } \\
\text { relevansi konten materi dengan memaparkan data dan fakta keadaan konten materi } \\
\text { superkelas pisces selama ini. Artikel ini hadir melalui penelitian dengan menggunakan } \\
\text { pendekatan kualitatif tipe studi pustaka (library research). } \\
\text { Kata kunci: Materi, Relevansi, Sekolah, Superkelas Pisces, Taksnomi Hewan }\end{array}$ \\
\hline
\end{tabular}

This BIODIK : Jurnal IImiah Pendidikan Biologi is licensed under a CC BY-NC-SA (Creative Commons Attribution-ShareAlike 4.0 International License) 


\section{PENDAHULUAN}

Pisces dalam istilah bahasa Indonesia dikenal sebagai "ikan" yang meliputi semua jenis ikan, baik yang tidak mempunyai rahang (termasuk ke dalam superkelas: Agnatha) maupun ikan yang mempunyai rahang (termasuk ke dalam superkelas: Gnathostomata) yang terdiri dari ikan bertulang rawan (kelas chondrichthyes) dan ikan bertulang sejati (kelas osteichthyes) (Pratomo \& Rosadi, 2010). Ikan merupakan kelompok vertebrata yang paling beraneka ragam, dengan jumlah spesies lebih dari 27.000 spesies di seluruh dunia. Struktur tubuh ikan sebagian besar dibentuk oleh rangkanya, tulang penyusun tubuhnya ada tulang rawan, dan adapula tulang sejati. Insang dan ekor yang mereka miliki membantu mereka untuk bergerak dengan cepat didalam air.

Untuk memperluas khasanah ilmu pengetahuan mengenai pisces, tidak akan lepas dari penelitian-penelitian yang terus dikembangkan oleh para ahli untuk menghasilkan penemuan-penemuan baru tentang superkelas pisces. Penemuan ilmiah yang dihasilkan akan benar-benar bermutu dan bermanfaat jika proses untuk memperoleh penemuan tersebut menggunakan metode ilmiah yang dilandasi sikap ilmiah peneliti. Taksonomi memiliki peran yang sesungguhnya dirasakan dalam berbagai jalur kehidupan, mulai dalam kehidupan sehari- hari misalnya dalam menentukan pilihan bahan pangan, objek untuk hiburan, pencegahan penyakit, dan banyak segi kehidupan lain yang berkaitan dengan makhluk hidup (Saptasari, 2013).

Berdasarkan hal itu sudah ada bentuk pemanfaatan perkembangan ilmu pengetahuan mengenai superkelas pisces ini dalam pembelajaran biologi yang lebih jauh kita kenal sebagai format penerapan cabang ilmu taksonomi hewan di sekolah. Materi Biologi di sekolah yang salahsatunya dapat dipelajari melalui kegiatan pengamatan yaitu Superkelas Pisces karena merupakan salah satu jenis vertebrata yang mudah dan sering ditemukan siswa sehari-hari. Materi Superkelas Pisces terdapat dalam dalam Kompetensi Dasar 3.8 yaitu menerapkan prinsip klasifikasi untuk menggolongkan hewan ke dalam filum berdasarkan pengamatan anatomi dan morfologi serta mengaitkan peranannya dalam kehidupan dan Kompetensi Dasar 4.8 yaitu menyajikan data tentang perbandingan kompleksitas jaringan penyusun tubuh hewan dan perannya pada berbagai aspek kehidupan dalam bentuk laporan tertulis (Indrawati, 2017).

Dalam pembelajaran biologi di sekolah sebagai bentuk penerapan dari ilmu taksonomi sangat perlu konsep-konsep yang relevan pada materi pisces khusunya mengenai klasifikasi pada superkelas ini. Pembelajaran mengenai klasifikasi ini merupakan salah satu bentuk penerapan atau aplikasi taksonomi hewan di sekolah, dimana siswa akan diperkenalkan kepada berbagai jenis ikan yang mudah dijumpai hingga yang tidak mudah dijumpai dalam kehidupan sehari-hari. Informasi mengenai contoh-contoh representatif pada superkelas pisces dengan jumlah spesies lebih dari 27.000 spesies di seluruh dunia harus diterima oleh siswa dengan baik, sehingga tujuan pembelajaran yang juga merupakan aplikasi taksonomi hewan di sekolah tercapai dengan efektif dan efisien.

Kurikulum 2013 merupakan kurikulum yang sangat cocok dan mendukung dalam penerapan pembelajaran kontekstual seperti taksonomi hewan. Kurikulum menjadi 
wadah dengan menyediakan rancangan-rancangan khusus sesuai kebutuhan siswa. Sudah ada Kajian ilmiah mengenai alasan pentingnya penerapan kurikulum 2013 dengan memaparkan data dan fakta penerapan kurikulum 2013 selama ini dan masih sangat relevan digunakan dalam pendidikan (Fernandes, 2019).

Akan tetapi relevansi tersebut belum semuanya dapat kita lihat dalam konsepkonsep yang dituangkan pada materi superkelas pisces. Miskonsepsi masih sering ditemukan pada pembahasan ini, antara lain pada buku paket, bahan ajar yang digunakan, modul yang digunakan guru hingga referensi-referensi lain yang dijumpai di sekolah. Contohnya dapat ditemukan pada konsep ciri-ciri superkelas pisces dimana guru dan siswa masih sering membahas salah satu ciri-cirinya berdarah dingin. Pada dasarnya berdarah panas memberikan pemahaman kepada siswa ikan benar-benar memiliki darah yang suhunya panas. Miskonsepsi terbentuk dikarenakan siswa kerap kali menggunakan gagasan yang berbeda untuk menginterpretasikan konsep-konsep (Dahar, 2011). Kemudian pengayaan pada materi ini juga sangat perlu dilakukan jika kita melihat kembali urgensi ilmu taksonomi yang bermanfaat dan mudah dipelajari secara kontekstual. Ditambah lagi dengan penemuan-penemuan baru seperti yang sebelumnya selalu membanjiri kanal-kanal publikasi ilmiah mengenai perkembangan superkelas pisces ini. Pembahasan yang dilakukan di sekolah belum sepenuhnya membawa informasi-informasi baru mengenai perkembangan ilmu taksonomi superkelas pisces. Materi seolah stagnan dan terkesan kaku, padahal perkembangan mengenai superkelas pisces ini sangat bermanfaat. Pengetahuan mengenai superkelas pisces menjadi modal dasar bagi siswa untuk berprofesi, menggeluti, dan berkecimpung di dunia perikanan nantinya. Hal inilah yang mengharuskan relevansi konsep superkelas pisces dalam pembelajaran biologi perlu dilihat kembali dalam aspek penerapan ilmu taksonomi di sekolah. Hal ini dikarenakan penerapan konsep pembelajaran superkelas pisces bersifat kontekstual, dan konsep pembelajaran yang kontekstual membangun hasil belajar yang bermakna dan bermanfaat dalam kehidupan nyata peserta didik (Gafur, 2003).

Penelitian ini sangat penting dilakukan untuk melihat gambaran-gambaran miskonsepsi dan kurang kompleksnya materi pada superkelas pisces yang belum relevan dengan kaidah-kaidah taksonomi hewan. Kemudian artikel ini juga memberikan saran bagaimana pengembangan dari materi superkelas pisces yang harus diberikan saat pembelajaran.

Berdasarkan latar belakang yang dipaparkan, melalui artikel ini akan diulas konten-konten apa saja yang perlu ditambahkan sebagai bentuk pengayaan mengenai superkelas pisces dalam pembelajaran di sekolah dan solusi untuk materi yang masih mengalami miskonsepsi. Artikel ini secara tidak langsung menyatakan sikap agar konten materi superkelas pisces ini selalu up to date dan menjadi materi yang paling menarik. Sikap tersebut akan dibuktikan secara ilmiah dengan memaparkan beberapa bentuk hasil-hasil riset baru dalam perkembangan superkelas pisces dengan kajian teori-teori pendidikan sebagai bentuk relevansi konsep klasifikasi superkelas pisces dari aspek penerapan ilmu taksonomi hewan di sekolah. Ulasan akan disampaikan berupa analisis miskonsepsi yang ditemukan hingga konten-konten penelitian terbaru 
dalam perkembangan taksonomi superkelas pisces yang sangat perlu dilakukan penambahan dan ditransformasi dalam penerapan ilmu taksonomi hewan.

\section{METODE PENELITIAN}

Artikel ini merupakan hasil studi dokumen dan kajian kepustakaan (library research). Data, informasi dan gagasan-gagasan konseptual dihimpun dari berbagai literatur, seperti: buku paket pembelajaran, artikel ilmiah, buku, laporan penelitian, dan berbagai media relevan. Penelitian ini analisis isi kurikulum melalui teknik content analytic guna memahami tujuan dan manfaat kurikulum biologi khusunya pemahaman mengenai superkelas pisces secara lebih dalam. Singkatnya, analisis penelitian ini mengadopsi pendekatan kualitatif, dan hasilnya disajikan secara deskriptif-analitis.

\section{HASIL DAN PEMBAHASAN}

\section{Miskonsepsi superkelas pisces sebagai hewan "berdarah dingin”.}

Ilmu taksonomi selalu identik dengan deskripsi rinci mengenai kelompokkelompok makhluk hidup, baik deskripsi ciri morfologi, anatomi, fisiologi, hingga perilaku. Tahap awal dalam penerapan ilmu taksonomi di sekolah melalui mata pelajaran biologi terlebih dahulu selalu menjelaskan beberapa ciri-ciri dari kelompok yang dijelaskan. Salah satu ciri yang sangat umum dibahas dalam superkelas pisces adalah termoregulasi dari superkelas pisces. Termoregulasi adalah kemampuan sistem otonomi saraf tubuh yang vital untuk berespon terhadap dingin dan heat stress. Suhu tubuh memiliki 2 komponen yaitu suhu inti tubuh dan suhu perifer tubuh. Suhu inti tubuh diukur dari suhu trunkus dan kepala, sedangkan suhu perifer tubuh diukur dari suhu ekstrimitas. Suhu inti tubuh cenderung lebih stabil dan dalam kondisi lingkungan moderat suhu perifer lebih rendah 2-4 derajat dibanding suhu inti tubuh (Prawara, Johan, \& Jusup, 2018). Seringkali dalam pembelajaran di kelas mengalami kesalahan konsep (miskonsepsi) mengenai termoregulasi dari superkelas pisces ini. Proses pembelajaran masih mentrasfer pengetahuan mengenai termoregulasi hewan ini dengan istilah "berdarah dingin" dan "berdarah panas", khusunya superkelas pisces yang terkenal dicirikan dengan "berdarah dingin". Istilah "berdarah panas" dan "berdarah dingin" pada dasarnya sudah luput dari pandangan di dunia sains. Hal ini dikarenakan konsep tersebut dikhawatirkan akan menyebabkan kesalahpahaman. Sebagai contoh, hewan yang sering disebut "berdarah panas" tidak selalu memiliki suhu darah yang panas, bahkan pada fase-fase tertentu bisa lebih dingin daripada hewan yang dikenal dengan hewan "berdarah dingin".

Hewan "berdarah panas" biasanya merujuk kepada kelompok hewan yang merupakan endotermik. Hewan tersebut merupakan kelompok hewan yang dapat menghasilkan, menggunakan, dan mempertahankan panas dari tubuhnya melalui aktivitas metabolismenya sebagai sumber energi termal. Hewan endotermik merupakan regulator panas. Sementara hewan "berdarah dingin" merujuk kepada kelompok hewan poikilotermik atau yang menggunakan panas dari lingkungan, atau konformer panas (Masturah, Hutabarat, \& Hartoko, 2014). 
Miskonsepsi mengenai termoregulasi superkelas pisces ini tentunya disebabkan oleh faktor-faktor tertentu. Miskonsepsi ini berasal dari niat baik siswa untuk mempelajari materi secara mandiri. Selain itu siswa juga mengambil kesimpulan yang salah, hanya menyimpulkan dari apa yang mereka lihat dan dengar tanpa mencari sumber aslinya. Masyarakat dan budaya juga dapat memperkuat miskonsepsi, terkadang ungkapan-ungkapan yang umum dalam bahasa pun salah dalam mempresentasikan makna yang sebenarnya. Sementara itu, gagasan yang keliru dari orang lain, guru, dan pengarang buku pelajaran juga menjadi sumber dari miskonsepsi (Ormrod, 2009).

Miskonsepsi pada dasarnya juga sulit untuk dihilangkan, berulang, dan mengganggu konsep berikutnya. Dalam pelaksanaan pembelajaran, kadang miskonsepsi disamakan dengan ketidaktahuan maka seringkali guru pada umumnya tidak mengetahui miskonsepsi yang lazim pada siswanya.

Hal inilah yang terjadi pada konsep termoregulasi superkelas pisces ini. Kebiasaan menyebitkan ikan berdarah dingin ini sudah melekat sehingga pemabahan siswa benar-benar menanggap darah dari kelompok ikan memang bersuhu dingin, dan akan kebingungan dengan konsep ini jika mengamati di lapangan mengenai suhu darah ikan.

Oleh karena itu, hal ini perlu diluruskan kembali mengenai ciri-ciri umum superkelas pisces terkait dengan termoregulasinya yang masih banyak disampaikan dengan konsep-konsep berdarah dingin. Guru yang berperan dalam pembelajaran biologi seharusnya merevisi miskonsepsi ini menjadi penjelasan termoregulasi yang sebenarnya, sehingga siswa tidak salah faham akan istilah "berdarah panas" atau "berdarah dingin". Penerapan ilmu taksonomi di sekolah perlu mengganti istilah tersebut dengan poikiloterm. Jika masih ada miskonsepsi maka konsep superkelas pisces yang diberikan sangat tidak relevan dari aspek penerapan ilmu taksonomi hewan di sekolah.

\section{Pengembangan materi ciri superkelas pisces dengan konten fisiologi mata ikan}

Deskirpsi mengenai respon hewan terhadap rangsangan sangat banyak dijelaskan dalam pembelajaran biologi di sekolah. Seringkali munculnya pertanyaan dari siswa dalam pembelajaran biologi mengenai penglihatan superkelas pisces. Ditambah lagi dengan karakteristik mata dari ikan yang selalu terbuka dan tidak pernah tertutup. Pertanyaan sederhana ini tidak dapat dijumpai dari penjelasan guru maupun susunan materi yang ada pada buku paket. Hal ini sangat dirasa perlu dilakukan penambahan pada penjelasan materi karakteristik ikan dengan penglihatannya, sehingga mnimbulkan pertanyaan oleh siswa "bagaimana ikan bisa melihat?".

Cahaya adalah salah satu faktor lingkungan yang penting dalam kehidupan ikan. Efek langsung yang utama adalah pada penglihatan. Cahaya yang masuk melalui mata maupun pineal region dapat mempengaruhi aktivitas ikan melalui mekanisme fisiologis retina mata ikan yang diteruskan ke pusat otak melalui sistem syaraf pusat. Adaptasi fisiologis retina mata tersebut tergantung dari struktur retina mata, kemampuan dan sensitivitas penglihatan. Pada intensitas cahaya yang relatif rendah peranan photoreseptor rod dalam retina mata lebih menonjol yang disebut sebagai 
scopotic vision dan pada intensitas yang lebih tinggi receptor cone relatif lebih berperan yang disebut sebagai photopic vision. Adanya stimuli cahaya menyebabkan pengaruh langsung maupun tak langsung terhadap kecepatan renang ikan dan ruaya ikan secara vertikal harian sebagai respon tingkah laku (Syam \& Satria, 2017). Secara umum terdapat adanya perbedaan tingkah laku ikan dalam merespon warna cahaya di sekitar lingkungannya (Razak, Anwar, \& Baskoro, 2005).

Berdasarkan hal diatas, penjelasan mengenai fisiologi mata ikan dalam menerima rangsangan cahaya perlu ditambahkan pada konsep-konsep superkelas pisces dalam menjawab pertanyaan terkait bagaimana superkelas pisces menggunakan penglihatan.

\section{Pengembangan konsep pada Agnatha, Condrichtyes, dan Osteichtyes: analisis relevansi dan peran penting materi}

Kurikulum adalah perangkat atau rencana yang disusun untuk mencapai tujuan pendidikan dengan adanya beberapa perubahan perubahan sesuai dengan perkembangan jaman. Semua faktor yang sangat berhubungan dimana semua faktor akan harus bermutu dan bekerja sama untuk proses peningkatan mutu satuan pendidikan (Budi, 2019).

Gambaran umum yang ditemukan dalam penyajian konsep pada pembelajaran biologi didalam buku paket, penjelasan guru, dan referensi lainnya untuk klasifikasi superkelas pisces adalah membagi superkelas ini menjadi tiga kelompok besar yaitu kelompok agnatha, condrychtyes, dan osteichtyes. Kelompok agnatha pada beberapa buku paket biologi dan sumber lainnya yang digunakan untuk pembelajaran biologi sangat singkat dan memberikan contoh representatifny adalah spesies Petromyzon marinus (ikan lamprey), atau kelompok-kelompok Petromyzon lainnya. Bentuk tubuh dari Agnatha ini silindris yang akan memanjang dan memiliki ukuran itu berkisar 76-90 $\mathrm{cm}$. Agnatha ini tidak memiliki suatu rahang tapi agnatha ini memiliki mulut yang bisa berbentuk sebuah lingkaran dan juga berparut, memiliki lidah dan juga gigi yang akan tersusun dari zat tanduk, tidak mempunyai sirip yang berpasangan, tidak bersisik, dan juga mempunyai tubuh yang lunak serta berlendir. Chondrichthyes merupakan kelompok ikan mempunyai bentuk tubuh yang tertutup oleh sisik-sisik plakoid kasar ytang berisi dentin (mesodermal) dan dilapisi dengan email (ektodermal). Kelompok Condrychtyes sering diberikan contoh representatif ikan hiu dan ikan pari. Sedangkan untuk kelompok Osteichtyes, yang biasanya menyajikan pembahasan yang cukup panjang, akan tetapi memberikan contoh-contoh representatif ikan air tawar dan ikan air laut yang mudah ditemukan saja.

Agnatha merupakan kelompok pertama yang dipelajari dalam materi superkelas pisces. Pada dasarnya kelompok agnatha pada materi biologi dijelaskan sebagai kelompok yang diantara spesiesnya sudah punah. Agnatha dicirikan kelompok ikan yang tidak memiliki rahang, mulut seperti mangkok, dikelilingi oleh tentakel. Jika dilihat relevansi konsep-konsep pembelajaran pada kelompok agnatha, sangat perlu dilakukan pengembangan materi dengan memberikan contoh representatif terbaru dari riset-riset mengenai kelompok agnatha. Hal ini sangat berkaitan dengan pengembangan kurikulum pendidikan biologi yang harus memperbaharui konten 
materi dengan contoh representatif penemuan-penemuan baru dalam superkelas pisces.

Pengembangan materi yang dapat mengambil contoh representatif pada kelompok agnatha adalah deskripsi mengenai spesies baru ditemukan yakni Eptatretus albiderma. Whitish hagfish atau Eptatretus albiderma sp. Nov, dikumpulkan dari Laut Timur Laut Vietnam (Da Nang). Spesies baru ini memiliki enam pasang lubang insang, tiga multikusp, 18-21 pori lendir prebranchial, pori lendir tidak ada atau satu cabang, dan warna tubuh keputihan hingga merah muda. Eptatretus albiderma sp. nov. dapat dengan mudah dibedakan dari Eptatretus atami (Dean, 1904) dan Eptatretus sheni (Kuo, Huang \& Mok, 1994) dengan jumlah katup total 41-43, warna tubuh (keputihan pada bagian punggung, lebih terang pada bagian perut, bintik mata (tidak ada atau samar, dan pori-pori lendir total 74- 78. Spesies baru ini secara jelas dibedakan dari $E$. atami dengan 0,026 jarak genetik berpasangan dari filogeni berdasarkan mtDNA COI (Song \& Kim, 2020). Dari contoh diatas dapat kita integrasikan kedalam konsep-konsep dari superkelas pisces, dimana spesies baru tersebut ditemukan siring dengan perkembangan zaman, dimana sebelumnya spesies ini tidak pernah ditemukan dan dibahas.

Sedangkan pengembangan yang dapat dilakukan pada materi kelompok Chondrichtyes adalah penemuah spesies Holocephali. Spesies ini merupakan hasil penelitian terbaru dari klasifikasi chondrichtyes. Holocephali adalah kelompok utama ikan chondrichthyan (bertulang rawan), kerabat dekat dari hiu dan pari (Elasmobranchii). Deskripsi yang membedakan dengan jenis lain yakni gigi holocephalans yang masih ada sangat berbeda dari gigi elasmobranch, tidak memiliki pembaruan gigi individu, tetapi terdiri dari plat gigi yang seluruhnya terbuat dari dentin yang memperbaharui sendiri. Dari penemuan ini, konten materi Condrichtyes akan sangat menarik dengan deskirpsi spesies baru, dimana hanya mengalami evolusi pada bagian tubuh tertentu (gigi). Peristiwa tersebut dapat mengembangkan materi kearah yang lebih baru mengenai Chondrychtyes, Sebelumnya kelompok ini dikenal dengan ikan bertulang rawan, dan perbedaan evolusi pada gigi sangat menunjukkan ciri khas spesies ini menjadi contoh representatif dibanding dengan contoh-contoh sebelumnya yang sering ditampilkan. Evolusi tersebut dapat dijelaskan dimana pembaruan semua jaringan terjadi pada permukaan pelat postero-lingual, sebagai fungsi dari kondisi statodontnya. Rekaman fosil holocephalans menerangi berbagai tren berbeda dalam gigi, termasuk gigi seperti hiu hingga gigi yang sama sekali tidak memiliki gigi individu. Takson yang berbeda menggambarkan retensi perkembangan gigi tetapi dengan fusi dalam perkembangan serialnya. Berbagai jenis dentin terdiri dari gigi-gigi ini dan plat gigi komposit, yang histologinya meliputi tabung vaskularisasi di dalam dentin koronal, bergabung dengan dentin trabekuler basal. Pada dentin koronal vaskularisasi ini, hipermineralisasi ekstensif membentuk jaringan tahan aus yang diubah menjadi berbagai morfologi. Melalui evolusi, dentin yang mengalami hipermineralisasi menjadi tertutup di dalam dentin trabekuler, dan terspesialisasi dengan reduksi menjadi zona tertentu di dalam plat gigi komposit, dengan peningkatan disparitas morfologis, semuanya mencerminkan hilangnya gigi yang ditentukan tetapi 
retensi produksi dentin dari paket perkembangan yang diwariskan (Johanson et al., 2020).

Contoh lain yang bisa diambil dari penemuan terbaru adalah catshark. Spesies catshark, Scyliorhinus ditinjau dan dideskripsikan ulang di sini, dengan deskripsi rinci tentang morfologi eksternal, neurokranium, claspers, dentikel dermal, dan morfologi gigi disediakan untuk pertama kalinya untuk semua spesies. Enam belas spesies diakui kerabat antara lain Scyliorhinus boa (Goode \& Bean, 1896), S. cabofriensis Soares, Gomes \& de Carvalho, 2016, S. canicula (Linnaeus, 1758), S. capensis (Müller \& Henle, 1838), S cervigoni Maurin \& Bonnet, 1970, S. comoroensis Compagno, 1988, S. duhamelii (Garman, 1913), S. garmani (Fowler, 1934), S. haeckelii (Miranda Ribeiro, 1907), S. hesperius Springer, 1966, S. meadi Springer, 1966, S. retifer (Garman, 1881), S. stellaris (Linnaeus, 1758), S. torazame (Tanaka, 1908), S. torrei Howell-Rivero, 1936, dan S. ugoi Soares, Gomes \& Gadig, 2015. Keputusan taksonomi utama yang diambil di sini termasuk kebangkitan S. duhamelii (sebelumnya merupakan sinonim junior S. canicula) dan sinonimisasi S. tokubee dengan S. torazame. Informasi tentang distribusi geografis telah dimutakhirkan untuk sebagian besar spesies, terutama untuk spesies dengan kisaran yang luas (S. canicula, S. haeckelii, S. retifer, dan S. stellaris) (Soares \& De Carvalho, 2019).

Sedangkan untuk pengembangan pada kelompok osteichtyes dapat dilihat dengan menampilkan contoh representatif pada penemuan tahun 2020 dengan spesies Dollfusentis lenti. digambarkan dan dicirikan dengan memiliki batang tubuh yang memanjang dengan duri yang tersebar jarang (panjang terbesar $60-85 \mu \mathrm{m}$ ) memanjang dari leher hingga hampir mencapai ujung wadah belalai. Selain itu, spesies baru ini memiliki belalai panjang dengan 12-14 baris longitudinal masingmasing 16-17 kait; 3-4 kait posterior berkurang ukurannya, berjarak cukup dari delapan kait bulan sabit ventrolateral, dan lemnisci lebih panjang dari wadah proboscis. Urutan baru susunan DNA 18S rDNA, ITS1, 5.8S dan ITS2, 28S rDNA dan COI mtDNA disediakan. Sedangkan spesies lain, Dollfusentis bravoae secara morfologis serupa karena memiliki jumlah kait belalai yang sama, meskipun berbeda menurut ukuran testis dan uterus dan dengan jumlah tulang belakang yang lebih banyak; Selain itu, pemindaian mikrograf elektron baru dan data genetik untuk kedua spesies mendukung perbedaannya. Analisis filogenetik yang diperoleh baik dengan dua gen inti maupun gen COI mitokondria menunjukkan bahwa Dollfusentis spp. termasuk dalam Illiosentidae, dan spesies baru dihasilkan sebagai spesies saudara D. bravoae, dengan D. chandleri sebagai spesies saudara dari dua spesies terakhir (Keidel, García-Varela, Brener, de León, \& Santos, 2019).

Dari uraian diatas dapat dilihat penemuan baru pada kelompok agnatha dengan nama ilmiah ikan Eptatretus albiderma, kelompok condrichtyes dengan nama ilmiah ikan Holocephali, dan kelompok Osteichtyes dengan nama ilmiah Dollfusentis lenti. Semuanya merupakan spesies-spesies baru yang ditemukan pada tahun 2019-higga 2020 sekarang.

Setelah memaparkan ide pengembangan materi diatas dengan berlandaskan penemuan-penemuan baru mengenai kelompok-kelompok pada superkelas pisces dapat kita nyatakan pembaharuan konten materi sangat perlu dilakukan setiap saat. 
Hal ini guna menunjukkan relevansi konsep pada superkelas pisces terhadap aspek penerapan ilmu taksonomi hewan di sekolah sebagai cabag biologi yang selalu mengalami perkembangan harus ditingkatkan. Pada dasarnya pengintegrasian hasilhasil penemuan baru pada masing-masing kelompok ikan ini merupakan pengetahuan baru dan penambahan wawasan bagi siswa, dengan memandang beberapa spesies yang dijabarkan merupakan spesies-spesies unik. Sebelumnya beberapa penelitian yang telah melakukan pengembangan pada materi superkelas pisces sudah pernah dilakukan. Adapun penelitian yang dilakukan Destiara tahun 2020, dengan menguji efektifitas bahan ajar berbasis lokal pada superkelas pisces. Salah satu materi yang erat dikaitkan dengan potensi lokal adalah pada konsep vertebrata sub materi pisces. Pisces merupakan jenis vertebrata yang banyak habitatnya di air. Berdasarkan observasi pada materi ajar pisces pada buku belajar siswa kelas X SMA dan MA, disebutkan beberapa jenis ikan namun contoh spesies seperti Agnatha, Chondrichthyes dan Osteichthyes yang tampil pada buku tidak familiar. Oleh sebab itu perlu ada pengenalan jenis spesies yang lebih familiar yang sering dijumpai agar lebih mudah dipahami dan dimengerti, kemudian dikemas dalam sebuah bahan ajar (Destiara, 2020). Hal ini memang sangat efektif dilakukan dengan mengarahkan siswa kedalam contoh-contoh yang lebih familiar, akan tetapi pada hakikatnya belum mendukung penerapan ilmu taksonomi di sekolah secara menyeluruh dengan prinsip ilmu yang senantiasa berkembang. Pemberian contoh yang representatif sesuai dengan penemuan-penemuan baru sangat perlu dilakukan, dengan tidak hanya memberikan contoh spesies-spesies lokal tetapi juga memberikan percontohan dari spesies yang menjadi hasil penemuan terbaru dalam dunia taksonomi hewan. Secara umum hasil analisis mengenai miskonsepsi dan kurang kompleksnya materi superkelas pisces dalam pembelajaran biologi di tingkat SMA/MA/SMK adalah:

Tabel 1. Hasil analisis miskonsepsi dan kurang kompleksnya materi

\begin{tabular}{|c|c|c|c|}
\hline No & Aspek yang diamati & Keterangan & Saran \\
\hline 1 & Ikan berdarah dingin & Miskonsepsi & $\begin{array}{l}\text { Sebutan ikan berdarah dingin mestinya } \\
\text { dihindari agar tidak menimbulkan } \\
\text { kesalahfahaman bagi siswa dalam } \\
\text { pembelajaran biologi. Seharusnya dijelaskan } \\
\text { mengenai termoregulasi pada ikan }\end{array}$ \\
\hline 2 & Kelas Agntatha & $\begin{array}{l}\text { Miskonsepsi/kelengkapan } \\
\text { materi }\end{array}$ & $\begin{array}{l}\text { Memberikan contoh representatif terbaru } \\
\text { sesuai hasil penelitian-penelitian terbaru }\end{array}$ \\
\hline 3 & Fisiologi mata ikan & Miskonespsi & $\begin{array}{l}\text { Konsep yang diajarkan guru belum bisa } \\
\text { mengatasi pertanyaan ssiwa bagaimana ikan } \\
\text { bisa melihat. }\end{array}$ \\
\hline
\end{tabular}

Pembelajaran biologi mengenai superkelas pisces semestinya tidak membuat pengetahuan yang kaku dan tidak menunjang pengetahuan yang luas tentang ikan. Akan tetapi memberikan kesempatan kepada siswa bagaimana menggali informasi mengenai ikan sebanyak mungkin. Maka langkah awal dari materi yang tersedia dengan mengemukakan pengetahuan-pengetahuan baru yang up to date. Dalam era pembelajaran digital, tidak dikhawatirkan siswa kurang mampu mencari informasi mengenai ikan dengan berselancar diinternet. Saat ini budaya literasi selalu 
ditegakkan. Pencarian data mengenai superkelas pisces sangat banyak tersedia di internet. Akan tetapi hal ini kembali harus dikemas dengan baik oleh konten materi yang tersedia dalam pembelajaran di sekolah maupun yang tertuang didalam buku paket dengan mengintegrasikan konsep yang benar agar tidaklagi menimbulkan miskonsepsi seperti yang dibahas sebelumnya.

Relevansi materi ini dengan penerapan ilmu taksonomi hewan di sekolah juga dapat ditingkatkan dengan cara integrasi materi baru pada konten materi esensial maupun pengayaan. Secara umum pengayaan dapat diartikan sebagai pengalaman atau kegiatan peserta didik yang melampaui persyaratan minimal yang telah ditentukan oleh kurikulum dan tidak semua peserta didik dapat melakukannya (Sugihartono, 2012). Secara umum tujuan program pengayaan untuk meningkatkan pemahaman dan wawasan terhadap materi yang sedang atau telah dipelajarinya serta agar siswa dapat belajar secara optimal baik dalam hal pendayagunaan kemampuannya maupun perolehan dari hasil belajar (Usman \& Lilis, 1993). Untuk materi superkelas pisces ini pengayaan juga sangat tepat sekali untuk dilakukan, dengan konsep dan contoh-contoh representatif dari penemuan baru dari kelompokkelompok ikan tersebut diletakkan pada suatu bagian khusus. Dengan hal ini, relevansi materi juga dapat ditingkatkan.

Tidak dapat dipungkiri juga pemahaman siswa mengenai ikan ini amatlah penting. Siswa akan mengetahui bagaimana ilmu taksonomi ini berperan dengan penerapannya di sekolah melalui pembelajaran biologi. Dengan mengetahui klasifikasi superkelas pisces atau ikan ini, dapat mengetahui kelompok ikan mana yang layak dikonsumsi dan tidak, kemudian mengetahui jenis apa yang pantas untuk dibudidayakan, dan jenis apa yang dapat dijadikan obat-obatan.

\section{KESIMPULAN}

Berdasarkan analisis terhadap konten-konten materi pembelajaran klasifikasi superkelas pisces yang terdiri dari konsep ciri-ciri superkelas pisces dan klasifikasi superkelas pisces dapat disimpulkan bahwa konsep-konsep yang ada dalam materi superkelas pisces perlu ditingkatkan relevansinya dalam penerapan ilmu taksonomi hewan melalui pembelajaran biologi di sekolah. Dalam hal ini miskonsepsi yang ditemukan masih perlu diperbaiki dan beberapa konten yang sangat penting perlu ditambahkan termasuk mengintegrasikan pengetahuan baru mengenai klasifikasi superkelas pisces ini melalui integrasi penemuan-penemuan baru yang membanjiri kanal-kanal publikasi ilmiah. Dalam artikel ini penulis ingin menegaskan bahwa pembelajaran yang bersifat kaku dan memberikan kesan ilmu taksonomi tidak merupakan ilmu yang luas akan mengganggu penerapan ilmu taksonomi di sekolah melalui pembelajaran biologi.

\section{DAFTAR PUSTAKA}

Budi, B. (2019). Dimensi Pembaharuan Dalam Peningkatan Mutu Pendidikan. Hijri, $8(2), 38-53$.

Dahar, R. . (2011). Teori- Teori Belajar. Jakarta: Erlangga. 
Destiara, M. (2020). Efektifitas Bahan Ajar Berbasis Potensi Lokal Pada Materi Pisces terhadap Hasil Belajar. Bioeduca: Jurnal Pendidikan Biologi, 2(2), 7-12.

Fernandes, R. (2019). Relevansi Kurikulum 2013 dengan kebutuhan Peserta didik di Era Revolusi 4.0. Jurnal Socius: Jorunal of Sociology Research and Education, 6(2), 70-80. https://doi.org/https://doi.org/10.24036/scs.v6i2.157

Gafur, A. (2003). Penerapan konsep dan prinsip pembelajaran kontekstual (Contextual Teaching and Learning) dan Desain Pesan dalam Pembelajaran dan Bahan ajar. Cakrawala Pendidikan, 22(3), 273-289

Indrawati, P. (2017). Pengembangan LKS Pengamatan dengan Pendekatan Saintifik (5M) pada Materi Superkelas Pisces untuk Pembelajaran Biologi Kelas X. BioEdu, 5(2), 19-34.

Johanson, Z., Manzanares, E., Underwood, C., Clark, B., Fernandez, V., \& Smith, M. (2020). Evolution of the Dentition in Holocephalans (Chondrichthyes) Through Tissue Disparity. Integrative and Comparative Biology, 60(3), 630-643.

Keidel, L., García-Varela, M., Brener, B., de León, G. P. P., \& Santos, C. P. (2019). Integrative taxonomy reveals a new species of Dollfusentis (Acanthocephala: Illiosentidae), in Orthopristis ruber (Osteichthyes: Haemulidae) from Rio de Janeiro, Brazil. Parasitology International, 71(1), 132-142.

Masturah, H., Hutabarat, S., \& Hartoko, A. (2014). Analisa Variabel Oseanografi Data Modis Terhadap Sebaran Temporal Tenggiri (Scomberomorus commersoni, lacepede 1800) di Sekitar Selat Karimata. Journal of Management of Aquatic Resources, 3(4), 11-19.

Ormrod, J. . (2009). Psikologi Pendidikan Membantu Sisiwa Tumbuh dan Berkembang Jilid I. Jakarta: Erlangga.

Pratomo, H., \& Rosadi, B. (2010). Identifikasi Pisces. Jakarta: Universitas Terbuka.

Prawara, A. S., Johan, A., \& Jusup, I. (2018). Pengaruh Pemberian Vitamin C Terhadap Kadar Glutation (GSH) Tikus Sprague Dawley yang Terpapar Heat Stress. Jurnal Kedokteran Diponegoro, 7(1), 39-48.

Razak, A., Anwar, K., \& Baskoro, M. S. (2005). Fisiologi Mata Ikan. Bogor: Institut Pertanian Bogor.

Saptasari, M. (2013). Pembelajaran Berbasis Kontekstual Sebagai Upaya Peningkatan Minat Mahasiswa pada Taksonomi Tumbuhan di Perguruan Tinggi. Jurnal Pendidikan Dan Pembelajaran (JPP), 19(2), 196-203.

Soares, K. D., \& De Carvalho, M. R. (2019). The Catshark Genus Scyliorhinus (Chondrichthyes: Carcharhiniformes: Scyliorhinidae): Taxonomy, Morphology and Distribution. Zootaxa, 460(1), 1-47. 
Song, Y. S., \& Kim, J. K. (2020). A New Species of Hagfish, Eptatretus albiderma sp. nov.(Agnatha: Myxinidae), from Vietnam, with the Keys to Species of Eptatretus in East Asia. Marine Biodiversity, 50(5), 1-9.

Sugihartono, S. (2012). Psikologi Pendidikan. Yogyakarta: UNY Press.

Syam, A. R., \& Satria, H. (2017). Adaptasi Fisiologis Retina Mata dan TGingkah Laku Ikan Terhadap cahaya. Bawal: Widya Riset Perikanan Tangkap, 2(5), 215-224.

Usman, M. ., \& Lilis, S. (1993). Upaya Optimalisasi Kegiatan Belajar Mengajar. Bandung: Remaja Rosdakarya. 